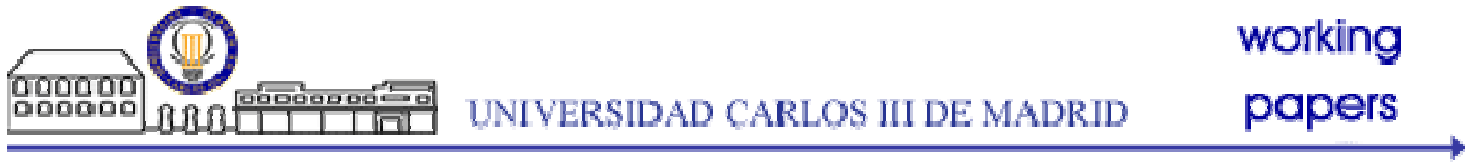

Working Paper 06-70

Economic Series 27

Departamento de Economía

December 2006

Universidad Carlos III de Madrid

Calle Madrid, 126

28903 Getafe (Spain)

Fax (34-91) 6249875

\title{
THE WEALTH DISTRIBUTION WITH DURABLE GOODS*
}

\author{
Antonia Díaz a and María José Luengo-Prado ${ }^{\mathrm{b} \dagger}$ \\ ${ }^{a}$ Department of Economics, Universidad Carlos III, 28093 Getafe Madrid, SPAIN \\ ${ }^{b}$ Department of Economics, Northeastern University, Boston, MA 02155-5000 U.S.A.
}

\begin{abstract}
This paper studies the effect that illiquid assets and collateral credit frictions have on the level of wealth inequality in a standard model of ex-ante heterogenous agents with idiosyncratic uncertainty. We calibrate our model so that its steady state statistics match selected aggregate statistics of the U.S. economy and data on the earnings distribution. We find that adding illiquid assets and collateral credit frictions decreases wealth inequality decreases slightly relative to an economy with liquid assets and no credit frictions. The effect is small because these frictions mostly affect poor households that account for a small fraction of aggregate wealth. Nevertheless, our richer model allows us to study other dimensions of wealth inequality. In particular, our model replicates the fact that financial assets are more concentrated than total wealth, while residential assets are less concentrated. Furthermore, we document that, in the U.S., the earnings and housing distributions are remarkably similar. Our model can account for this fact so long as the earnings process is fairly persistent
\end{abstract}

Keywords: Precautionary Saving, Wealth Distribution, Illiquid assets.

JEL Classification: E22, E23, Q43.

\footnotetext{
* This paper was previously entitled "Precautionary Saving and Wealth Distribution with Durable Goods". We would like to thank Ed Prescott, Victor Ríos-Rull, Javier Díaz-Giménez, Berthold Herrendorf, Josep Pijoan-Mas and Darin Lee for helpful comments as well as seminar participants at CEMFI, the University of Pennsylvania, Arizona State University, Carlos III, FEDEA, Universidad Complutense, Universidad de Málaga, EFACR, NBER Summer Institute 2002, Université Catholique de Louvain, Federal Reserve Bank of Minneapolis, Federal Reserve Bank of New York, Universidade de Madeira and CERGE-EI. Díaz thanks the Dirección General de Investigación, project SEJ2004-00968, for financial support. Luengo-Prado is indebted to the Dirección General de Investigación, project BEC2000-0173, for financial support.

† Corresponding Author: María J. Luengo-Prado, Department of Economics, 301 LA, Northeastern University, Boston, MA 02155-5000 U.S.A.; Telephone: +1-617-373-4520; Fax: +1-617-373-3640; Email: m.luengo@neu.edu.
} 


\section{Introduction}

In the United States, wealth is significantly more unequally distributed than earnings. Models with uninsurable idiosyncratic labor risk have been used widely to study the determinants of wealth inequality across households and to try to understand this fact (see Aiyagari 1994). In these models, wealth inequality arises because a market to insure specific earnings risks does not exist and households self-insure by accumulating an asset (assumed to be perfectly liquid) that is used to smooth consumption over time. Our contribution is to quantitatively study the determinants of wealth inequality in economies where households not only accumulate liquid financial assets, but can also save in the form of illiquid assets such as a house. In reality, houses also provide collateral for loans. The question that we address is whether the inclusion of illiquid assets that serve as collateral amplifies or mitigates the effect of uninsurable idiosyncratic labor risk on wealth inequality. This project is motivated by the fact that houses comprise almost 40 percent of the total wealth held by households in the U.S. economy. Moreover, according to the Survey of Consumer Finances, 92 percent of all available credit to consumers is collateral credit. Collateral debt accounts for 15.5 percent of aggregate household net worth and the average ratio of collateral credit to total debt across households is roughly 79 percent. ${ }^{1}$

In this paper, we build a general equilibrium model economy of ex-ante identical households who face uninsurable idiosyncratic shocks to their labor endowments. Households have two means of saving: liquid financial assets and illiquid houses. We model houses as assets that can be adjusted to any level at a given non-convex cost. Furthermore, houses can be financed (minus a down payment) and can be used as collateral for home equity loans. For simplicity, we allow no other form of credit. In our model, households derive utility from consumption of a nondurable good and from housing services. We assume there is no rental market for houses so households obtain housing services by purchasing residential stock. We calibrate the model economy so that its steady state statistics match selected aggregate statistics of the U.S. economy and data on the earnings distribution. In particular, we construct an earnings process that is a mixture of a process estimated directly from the data plus an extra shock that allows us to jointly match the observed level of earnings and wealth inequality. We assume there are two types of households, regular households and superstars. The process that governs the earnings of regular households is calibrated using data for households outside the top 1 percent of the earnings distribution of households with positive earnings in the 1998 Survey of Consumer Finances (SCF-98), and is very similar to the idiosyncratic component

\footnotetext{
${ }^{1}$ These figures are for 1998 and are similar in other years.
} 
of the earnings process estimated by Storesletten, Telmer, and Yaron (2004) using the Panel Study of Income Dynamics (PSID). We calibrate the superstar shock level and its persistence so that the overall Gini index for earnings and wealth match those observed in the data.

Our goal is to assess the role of illiquid assets in explaining the wealth distribution. To this end, we must compare our benchmark economy to the standard economy without illiquid assets considered in the literature. This comparison is not straightforward. We show that, in fact, Aiyagari's (1994) economy is equivalent to an economy with liquid houses, no down payments, home equity loans with a loan-to-value ratio of 1 , and a perfect rental market. We call this economy the one-asset economy. Using the same earnings process, we calibrate the one-asset economy to produce the same aggregates as our benchmark economy. We find that with illiquid assets and limited collateral loans wealth inequality is just slightly lower than in the one-asset economy. Wealth inequality is lower because the credit restriction implies that all households must hold some wealth in the form of the required down payment (this is not the case in the one-asset economy). The difference is small because the frictions of our model (required down payments and adjustment costs) mainly affect poor households that only account for a small fraction of aggregate wealth. Eliminating the superstars, introducing a rental market, or imposing a minimum size for the houses that households can purchase does not change our conclusions. However, when we lower the persistence of the earnings process, the frictions of our model have a larger effect because more households are affected by them.

In summary, the standard one-asset economy analyzed in the literature implicitly allows for collateral loans and the fact that one asset is illiquid does not have much of an effect over the wealth distribution. Nevertheless, our richer model allows us to study other dimensions of wealth inequality. For example, financial assets are more concentrated than total wealth, while residential assets are less concentrated than total wealth. Our model can replicate and explain these facts easily. Furthermore, we document that the earnings and the housing distributions are remarkably similar in the United States. Our model can account for this fact as long as the earnings process is fairly persistent. Finally, we can use our framework to analyze how changes in down payment requirements and the availability of home equity loans affect the economy. We find that as collateral credit expands, total wealth decreases, the interest rate increases and wealth inequality - measured by the Gini index - may worsen (more details are given throughout the paper). Furthermore, the easing of credit has a significant effect on the portfolios of poor households.

In our setup, the persistence of the earnings process for both regular households and superstars 
is essential to replicate the level of wealth inequality in the data. It is important to recognize that this is no different from the models that we build upon. Aiyagari (1994) already points out that the persistence of the process that governs households' earnings streams is key in explaining wealth inequality. This argument is elaborated further by Quadrini and Ríos-Rull (1997). The literature has explored several mechanisms that could amplify the effects of uninsurable labor shocks on the level of wealth inequality. For instance, Huggett (1996) examines the role of retirement and Social Security. Quadrini (2000) and Cagetti and Nardi (2005) study the interaction of uninsurable idiosyncratic labor risk and occupational choice, whereas Krusell and Smith (1998) and Carroll (2000) resort to changes in preferences to account for the observed level of wealth inequality. These papers have various degrees of success in jointly accounting for the observed level of earnings and wealth inequality but all of them stress the difficulty in reproducing the observed level of wealth inequality when the level of idiosyncratic labor risk is estimated using the PSID. Indeed, this is why Castañeda, Díaz-Giménez, and Ríos-Rull (2003) construct an earnings process that allows them to jointly account for the observed wealth and earnings inequality rather than use an earnings process estimated directly from the data. They show that the degree of earnings variability needed to account for the observed level of wealth inequality is much larger than the one estimated using the PSID. Our calibration exercise is similar to that of Castañeda, Díaz-Giménez, and Ríos-Rull (2003).

Our paper is part of an emerging literature that incorporates durable goods in heterogenous agents models. For instance, Díaz-Giménez, Prescott, Fitzgerald, and Alvarez (1992) model durables explicitly to study the welfare effects of alternative monetary policies. Díaz-Giménez and Puch (1998) analyze the welfare consequences of imposing different levels of borrowing constraints. More recently, Luengo-Prado (2006) shows that the explicit consideration of durable goods and collateral credit is useful for understanding the "excess smoothness" and "excess sensitivity" of consumption. Fernández-Villaverde and Krueger (2002) consider a model with liquid durables and replicate the hump-shaped evolution of durable and nondurable consumption expenditures over the life-cycle. Our work is closest to Gruber and Martin (2003), although our modelling strategy, calibration and focus is quite different. Whereas Gruber and Martin analyze how transaction costs affect the volume of precautionary saving, we are more interested in the impact of changes in collateral and illiquidity on the distributions of houses and financial assets, as well as the wealth composition. 


\section{The model economy}

We consider a production economy populated by a continuum of households of measure one who live forever. We focus our analysis on steady states. Sections 2.1, 2.2 and 2.3 describe the technology, the preferences and endowments, and the market arrangements, respectively. Section 2.4 presents the household problem and section 2.5 provides a formal definition of steady state equilibrium. Section 2.6 compares our model economy to the standard economy without illiquid assets.

\subsection{Technology}

Aggregate output, $Y$, is produced according to an aggregate Neoclassical production function that takes as inputs aggregate capital, $K$, and aggregate labor, $L: Y=F(K, L)$. The final good, can be either consumed, invested in capital or invested in durable goods on a one-to-one basis. Thus, the feasibility constraint is:

$$
C+I_{k}+I_{h}=F(K, L)
$$

where $C$ is nondurable consumption, $I_{k}$ is investment in capital, and $I_{h}$ is investment in residential stock. We assume that houses and capital depreciate at the rates $\delta^{h}$ and $\delta^{k}$ respectively.

\section{$2.2 \quad$ Preferences and endowments}

Households derive utility from the consumption of a nondurable good, $c$, and from the service flow, $s(h)$, provided by houses, $h$. They do not derive utility from leisure. We write the per period utility as $u(c, s(h))$, and lifetime utility as $\sum_{t=0}^{\infty} \beta^{t} u\left(c_{t}, s\left(h_{t}\right)\right)$, where $\beta$ is the time discount factor. Each period, households receive a shock to their efficiency units of labor $e \in E=\left\{e_{1}, \ldots ., e_{n_{e}}\right\}$. The shock is Markov with transition matrix $\pi_{e, e^{\prime}}$.

\subsection{Market arrangements}

We assume there are no state contingent markets for the household-specific shock. Households hold residential assets $h \in[0, \infty)$ and financial assets $a \in[\underline{a}, \infty), \underline{a} \in \mathbb{R}$. Financial assets pay a net interest rate $r$. For simplicity, we assume there are no differences between borrowing and lending rates. Furthermore, there is no rental market for housing services and houses provide collateral for 
loans. In particular:

$$
a \geq-(1-\theta) h
$$

This constraint implies that the maximum debt a household can incur is a fraction $(1-\theta)$ of the household's residential stock, which determines the lower bound for $a, \underline{a}$. The constraint summarizes several aspects of collateral lending observed in reality. First, when purchasing a house, a household can only finance a fraction $(1-\theta)$ of the house's value - i.e., the household must satisfy a down payment requirement $\theta .^{2}$ Second, when a household owns a house, the household can obtain a loan for up to a fraction $(1-\theta)$ of its value - i.e., there are home equity loans. In summary, at any point in time, a household is only required to keep an accumulated home equity of $\theta h$. Note that households cannot borrow if they do not own residential assets. Finally, we assume that changing the residential stock is costly and consider a non-convex cost of adjustment, $\tau\left(h^{\prime}, h\right)$.

\subsection{The household's problem}

The household's state variables are the labor endowment shock, capital holdings, and residential assets, $\{e, a, h\}$. The problem that a household solves is:

$$
\begin{aligned}
& v(e, a, h)=\max _{c \geq 0, h^{\prime} \geq 0, a^{\prime}} u\left(c, s\left(h^{\prime}\right)\right)+\beta \sum_{e^{\prime}} \pi_{e, e^{\prime}} v\left(e^{\prime}, a^{\prime}, h^{\prime}\right) \\
& \text { s.t. } \quad c+a^{\prime}+h^{\prime}-\left(1-\delta^{h}\right) h+\tau\left(h^{\prime}, h\right)=w e+(1+r) a, \\
& a^{\prime}+(1-\theta) h^{\prime} \geq 0 .
\end{aligned}
$$

\subsection{Stationary equilibrium}

For notational efficiency, we denote $x=\{e, a, h\}$ and $X=\{E \times[\underline{a}, \bar{a}] \times[0, \bar{h}]\}$. We construct a Markov process for the individual state variables from the Markov process on the shocks and the decision rules of the agents (see Huggett 1993 or Hopenhayn and Prescott 1992 for details). Let $\mathcal{B}$ be the $\sigma$-algebra generated in $X$ by, say, the open intervals. A probability measure $\mu$ over $\mathcal{B}$ exhaustively describes the economy by stating how many households there are of each type. Let

\footnotetext{
${ }^{2}$ In practice, financial institutions require down payments for a number of reasons. For example, down payments reduce the moral hazard problem in the care that owners take in maintaining the value of their house and they also mitigate the effects of the adverse selection problem that results from asymmetric information in the credit market.
} 
$P(x, B)$ denote the probability that a type $\{x\}$ has of becoming of a type in $B \subset \mathcal{B}$. The function $P$ naturally describes how the economy moves over time by generating a probability measure for tomorrow, $\mu^{\prime}$, given a probability measure, $\mu$, today. The exact way in which this occurs is:

$$
\mu^{\prime}(B)=\int_{X} P(x, B) d \mu
$$

To find a steady state, we look for the measure of households $\mu$ such that given the prices implied by that measure, households' actions reproduce the same measure $\mu$ in the following period. Formally, a steady state equilibrium for this economy is a set of functions for the household problem $\left\{v(x), g^{a}(x), g^{h}(x), g^{c}(x)\right\}$, and a measure of households, $\mu$, such that:

1. Factor inputs are obtained by aggregating over households: $K=\int_{X} a d \mu$, and $L=\int_{X} e d \mu$. Analogously, $H=\int_{X} h d \mu$.

2. Factor rental prices are factor marginal productivities: $r=F_{1}(K, L)-\delta^{k}$ and $w=F_{2}(K, L)$.

3. Given $\mu, K, L$ and $H$, the functions $\left\{v(x), g^{a}(x), g^{h}(x), g^{c}(x)\right\}$ solve the household's problem.

4. The markets for capital, nondurable consumption and houses clear: $\int_{X}\left[g^{a}(x)-\left(1-\delta^{k}\right) a\right] d \mu=$ $I_{k}, \int_{X} g^{c}(x) d \mu=C, \int_{X}\left[g^{h}(x)-\left(1-\delta^{h}\right) h+\tau\left(g^{h}(x), h\right)\right] d \mu=I_{h}$.

5. The feasibility constraint is satisfied: $C+I_{k}+I_{h}=F(K, L)$.

6. The measure of households is stationary: $x(B)=\int_{X} P(x, B) d \mu$, for all $B \subset \mathcal{B}$.

In our benchmark economy we abstract from a housing rental market. There are, however, several frictions in place, in particular, adjustment costs and a down payment. In order to understand the role of each friction as well as the importance of the rental market, we will compare our benchmark economy to an alternative economy where all these frictions are absent.

\subsection{The one-asset economy: an economy with a perfect rental market and without transaction costs or collateral requirements}

Our goal is to explore the role of illiquid assets in shaping the wealth distribution. In order to do this, we must compare our benchmark economy to the standard economy in the literature of heterogeneous agents with uninsurable idiosyncratic risk. An example of the latter framework is Aiyagari (1994). In his model there is a single liquid asset, net worth must be non-negative and 
households derive utility from consumption of a nondurable good only. The comparison of Aiyagari's economy and our benchmark economy is not straightforward. Nevertheless, we can construct an alternative economy that is equivalent to Aiyagari's. Assume that houses are liquid assets and that they can be fully financed $(\rho=0, \theta=0)$. Furthermore, assume there is a perfect rental housing market. Let $s$ denote housing services and $i$ the rental price of housing. The household's budget constraint becomes:

$$
c+a^{\prime}+h^{\prime}-\left(1-\delta^{h}\right) h+i s=w e+(1+r) a+i h,
$$

and the liquidity constraint is:

$$
a^{\prime}+h^{\prime} \geq 0
$$

In this economy, the consumption of housing services is not tied to housing asset holdings since households can purchase additional services in the market or rent part of their residential stock to others if so choose. In equilibrium, the return to financial assets and houses must be the same, $i=r+\delta^{h}$, and a household's level of nondurable consumption and housing services is invariant to the household's portfolio composition. That is, households only care about their total asset holdings, $a+h$. This economy, in equilibrium, is equivalent to Aiyagari's economy. Hereafter, we refer to it as the one-asset economy. We provide a more detailed description as well as an equilibrium concept in Appendix A.

\section{Calibration}

In this section, we present the calibration of our benchmark two-asset economy in the following order: the earnings process, the technology, preferences and market arrangements. Then, we present the calibration for the one-asset economy. Parameter values are summarized in Table 3.

\subsection{The earnings process}

To construct our earnings process we must decide on the statistics in the U.S. data that we would like to match. The first step is summarizing the data (we use data from the SCF-98). We construct measures for labor earnings, housing wealth, financial assets and household net worth. The labor earnings and net worth measures are constructed following Budria, Díaz-Giménez, Quadrini, and 
Ríos-Rull (2002). Briefly, labor earnings are computed as labor income plus a proportion of capital income attributed to labor for business owners, all before taxes and transfers. Net worth corresponds to total wealth in our model, $h+a$. Housing wealth corresponds to our variable housing stock, $h$, and measures the total value of the house (not just housing equity). Financial assets, $a$, are calculated as the difference between net worth and housing wealth for each household. In this setup, mortgages are a negative position in financial assets.

There are two main data sources on household earnings and wealth data that we could use: the PSID and the SCF. The PSID is a longitudinal data set and particularly useful for measuring earnings over time. However, the SCF is specifically designed to measure household wealth. According to Juster, Smith, and Sttaford (1999), the PSID underestimates the value of home equity for all homeowners when compared to the SCF by about 10 percent and the bias increases with a household's wealth. Juster, Smith, and Sttaford (1999) also find that while the PSID does a good job in representing household net worth for the bottom 99 percent of wealth distribution, it does a poor job for the top 1 percent. Also, in the PSID earnings are top coded. While the purpose of this paper is not to explain why earnings of the top 1 percent of the population are so large, we must acknowledge that the existence of these households may be important to understand the consumption and saving behavior for the rest of the population. Thus, for our calibration we rely mainly on the SCF.

Given that our model is dynastic with no life-cycle features or business owners, we choose to match wealth and earnings statistics for households with positive earnings. ${ }^{3}$ In the SCF-98, 77.71 percent of the households report positive earnings and they hold 78.85 percent of aggregate wealth. Table 1 shows, for the selected sample, the Gini coefficients and the distribution across quintiles of earnings, housing wealth, financial assets and total wealth, along with a portfolio composition measure (housing wealth over total wealth). For comparison purposes, we also report the same statistics for all households. The Gini index for earnings in the full sample is 0.606 vs. 0.497 for households with positive earnings. The Gini indices for houses and wealth, however, are very similar for both groups; 0.656 vs. 0.649 , and 0.796 vs. 0.804 , respectively. Likewise, the portfolio composition across quintiles, in the rows labeled $H / W$, are remarkably similar in both samples. This similarity give us confidence that our simplification may be without loss of generality.

To calibrate the earnings process, we proceed as follows. We divide households with positive earnings in two groups: superstars (the top 1 percent of the distribution) and regular households

\footnotetext{
${ }^{3}$ Households with zero earnings are mainly retirees, while households with negative earnings tend to be business owners.
} 
(the rest). We divide regular households in six groups of even size. For regular households we assume, as is standard in the literature, that log earnings follow the $\operatorname{AR}(1)$ process: $\log e_{t}=$ $\rho \log e_{t-1}+\eta_{t}$. We choose a highly persistent process, $\rho=0.989$, with volatility $\sigma_{\eta}^{2}=0.0158 .{ }^{4}$ This combination delivers a Gini index for earnings of regular households equal to 0.433 (vs. 0.432 in the data), and a coefficient of variation (CV) for earnings of 0.84 , very similar to the one in the SCF-98 for households outside the top 1 percent of the earnings distribution. ${ }^{5}$ We approximate the AR(1) process by a 6-point Markov chain using the procedures described in Tauchen (1986). Next, we choose the superstar earnings shock to be 6 times the highest shock for regular households (in the SCF-98 the equivalent number is $\left.e_{7} / e_{6}=6.26\right)$. We assume all regular households have the same probability of becoming a superstar. For simplicity, the probability that a superstar becomes a regular household of type $i=1, \ldots, 6$ is the same for all types. With these restrictions, we have two parameters left: the probability of becoming a superstar and the probability of becoming a regular worker. We chose them so that superstars represent 1 percent of the earnings distribution and the Gini index for wealth is that observed in the data, 0.804. The resulting overall Gini coefficient for earnings is also very close to the one observed in the data, (0.494 in the model vs. 0.497 in the data). Table 2 summarizes the process. Note that the probability of becoming a superstar is low, 0.05 percent, and the persistence of the shock is high - the probability of a superstar staying a superstar next period is 95.05 percent.

We calibrate the earnings process so that the Gini index for wealth in our benchmark economy is equal to that of the U.S. economy while also reproducing the Gini coefficient for earnings. Our objective is to understand the effect of the existence of illiquid assets on wealth inequality. Note that our calibration strategy is not inconsistent with our objective. The reason is the following. We want to determine whether illiquid assets, and the market frictions they entail, amplify (or mitigate) the effect of uninsurable idiosyncratic earnings risk on the level of wealth inequality. To this end, we compare two economies: our benchmark economy with all frictions in place and the one-asset economy, free of all those frictions. We calibrate both economies to produce the same aggregates and we use the same earnings process. Thus, the relevant comparison is in the difference in the level of wealth inequality observed in the one-asset economy compared to the benchmark economy.

\footnotetext{
${ }^{4}$ The persistence and volatility of the $\mathrm{AR}(1)$ process for regular household earnings we use are very similar to the numbers calculated by Storesletten, Telmer, and Yaron (2004) using data from the PSID for idiosyncratic earnings net of cohort effects $\left(\rho=0.9989\right.$ and $\left.\sigma_{\eta}^{2}=0.0166\right)$. Their earnings represent gross wage income plus transfers, slightly different from our definition. Moreover, they allow for transitory shocks and fixed effects (two types of households) which we do not model here.

${ }^{5}$ The CV for college graduates is 0.8 and for non-college graduates is 0.81 . When we combine them together, the $\mathrm{CV}$ is 0.88 . Since in our model all households are ex-ante identical, we choose the average of the combined sample and the individual samples.
} 
If wealth inequality was higher in the benchmark economy, we would conclude that illiquid assets and credit frictions amplify the effects of uninsurable idiosyncratic labor risk on wealth inequality and vice versa.

\subsection{Technology}

We need to construct measures of output, capital, the stock of houses $(Y, K, H)$, and their investment counterparts according to an appropriate criterion. We use data from the National Income and Product Accounts (henceforth NIPA) and the Fixed Assets Tables (henceforth FAT), both from the Bureau of Economic Analysis. We define capital as the sum of non-residential private fixed assets plus the stock of inventories plus consumer durables. Investment in capital, $I_{k}$, is defined accordingly. $H$ is private residential stock and $I_{h}$ is private residential investment. Finally, we need a measure of output, $Y$. In our benchmark economy, output consists of labor income plus income from non-residential capital: $Y=F(K, L)=w L+r K=C+I_{k}+I_{h}$. Thus, output is measured as GDP minus housing services. ${ }^{6}$ We proceed as Cooley and Prescott (1995) to calculate the capital share of our economy. We do not make any imputation to output for government owned capital since are focus is on privately held wealth. The implied share of capital in output is 0.26 . The capital-output ratio is 1.64 and the housing-output ratio is $1.07 .^{7}$ We set the depreciation rate of capital so that it matches the investment-capital ratio, 0.12 . The implied steady state interest rate is 3.91 percent. $^{8}$

Finally, we need a measure of GDP in our model economy. GDP is simply output, $Y$, plus housing services. We follow Cooley and Prescott (1995) and set GDP $=Y+i H$, where $i=r+\delta^{h}$ is the implicit rental price for housing services. The resulting capital-GDP ratio is 1.51 and the corresponding housing-GDP ratio is 0.98 . The aggregate ratio $(K+H) / G D P$ is 2.49 . The share of capital income to GDP in our model, once we impute housing services, is 31 percent, slightly lower than that estimated by Prescott (1986).

\footnotetext{
${ }^{6}$ We include net exports in our measure of capital investment.

${ }^{7}$ The ratio of residential stock to total net worth in the SCF-98 is 0.391, whereas in NIPA the corresponding ratio, $H /(H+K)$, is equal to 0.395 . Thus, both sources are consistent in the aggregate portfolio.

${ }^{8}$ The figures we report are averages for the sample period 1954-1999.
} 


\subsection{Preferences}

For preferences over consumption of the nondurable good and housing services, we follow LuengoPrado (2006) and use the separable utility function $u(c, s(\cdot))=\frac{c^{1-\sigma}}{1-\sigma}+\gamma \frac{s(\cdot)^{1-\sigma}}{1-\sigma}$. We assume that housing services are proportional to the housing stock and set the constant of proportionality to one. $\sigma$, the risk aversion parameter is 2. The calibration of $\gamma$ and $\delta^{h}$ is not straightforward due to the presence of adjustment costs. In the steady state, $I_{h}$ is $\delta^{h} H$ plus the aggregate adjustment cost. We choose values for $\gamma$ and $\delta^{h}$ to jointly match the ratio of housing to nondurable consumption and the housing-output ratio in NIPA $(H / C=1.40$ and $H / Y=1.07$, respectively). This implies $\gamma=0.166$ and $\delta^{h}=0.0367$. The discount factor, $\beta=0.9006$, is such that the net interest rate in the steady state is 3.91 percent.

\subsection{Market arrangements}

We use a down payment of 20 percent, slightly below the 25 percent average down payment for the period 1963-2001 reported by the Federal Housing Finance Board. Thus, individuals can borrow up to 80 percent of the value of the durable. ${ }^{9}$ While in reality households may be able to acquire houses with lower down payments, it is also the case that these households face higher marginal borrowing costs (including a higher interest rate and the purchase of mortgage insurance). To keep the model tractable, the down payment parameter is the same for all consumers and the borrowing rate is not a function of $\theta$. We report results for higher and lower down payments in section 5 to assess the robustness of our results.

We consider non-convex costs of adjustment in the market for houses, which result in infrequent changes of the residential stock. We assume households pay the adjustment cost every time the value of the stock changes. The idea underlying this assumption is that a household can buy a house of any desired size, but once it has been bought the stock is illiquid. In order to change the house, the household needs to sell the stock and selling it entails transaction costs. We assume that right after consuming housing services the stock depreciates at the rate $\delta^{h}$, and that if a household lets the house depreciate, the household must pay the adjustment cost (i.e., we force households to

\footnotetext{
${ }^{9}$ When purchasing a new residence, household must put a 20 percent down payment. Also, $(1-\theta)$ represents the maximum loan-to-value ratio for home equity loans. Note there are no fees associated to obtaining collateral loans in the model.
} 
do maintenance of the stock). ${ }^{10}$ In particular, the specification of the adjustment cost is:

$$
\tau\left(h^{\prime}, h\right)=I \rho\left(1-\delta^{h}\right) h,
$$

where $I=0$ if $h^{\prime}=h$, and 1 otherwise. This cost can be seen as a loss in the selling price when changing the housing stock. Note that once the household decides to change the stock, the adjustment cost is proportional to the inherited level of residential assets, $\rho\left(1-\delta^{h}\right) h$. With this specification, the transaction cost does not quickly diminish in importance as households become wealthier, as with a purely fixed cost. In our benchmark case, we set $\rho$ equal to 5 percent (the typical fee charged by real estate brokers in the U.S. economy is around 6 percent). Computational details on how to compute the model are given in Appendix C.

\subsection{The one-asset economy}

In an economy with no transaction costs, a zero down payment, and a perfect rental market, the return to financial assets is the same as the market return for housing. Therefore, the household portfolio composition cannot be determined. Additionally, the consumption of housing services is not tied to the household's holdings of residential assets. Households can acquire additional housing services or sell housing services to others in the rental market. In this case, the price of housing services affects the composition of the consumption basket (nondurable consumption vs. housing services) but not the savings decision. Thus, the household problem can be written in terms of two state variables, earnings and total assets $(a+h)$. More details are given in Appendix A.

Our calibration strategy is such that both the benchmark economy and the one-asset economy produce the same capital-output, housing-output and housing-nondurable ratios. The parameter in the utility function, $\gamma=0.161$, is chosen to match the ratio of residential stock to nondurable consumption in the data, $H / C=1.40 .{ }^{11}$ The depreciation rate of houses, $\delta^{h}$, is set so that it matches the housing investment-stock ratio in the data, 0.043. The discount factor, $\beta=0.904$, is chosen so that the ratio of total wealth to GDP, $(K+H) / G D P$ is equal to 2.49. The share of capital and the depreciation rate of capital do not change. Table 3 summarizes the calibration parameters for both the benchmark economy and the one-asset economy (the other rows in the

\footnotetext{
${ }^{10}$ The maintenance specification is convenient for computational reasons. Allowing for depreciation instead of imposing maintenance did not change the results significantly. However, the pattern of durable purchases would be very different in both cases. Allowing for depreciation generates $(S, s)$ dynamics for the household stock of houses while maintenance does not.

${ }^{11}$ From the F.O.C. of the problem, it is easy to show that $H / C=(\gamma / i)^{1 / \sigma}$.
} 
table correspond to alternative economies that are discussed later on).

\section{Results}

\subsection{The wealth distribution}

Table 4 shows wealth distribution and wealth composition statistics for the benchmark economy that we can compare to the ones from the data summarized in Table 1. Wealth is unequally distributed with a Gini index of 0.801 (this is because of our calibration strategy). In our model as in the data, houses are more equally distributed than financial assets. The Gini coefficient for houses is 0.483 (0.649 in the data), while the Gini coefficient for financial assets is 0.93 (0.945 in the data). ${ }^{12}$ Also, houses represent a smaller proportion of wealth for the rich (as in the data). Since the return to housing is the marginal utility of the services it renders and marginal utility is decreasing, this is not surprising. The model fares remarkably well in the wealth-composition dimension given that we abstract from several factors that may affect the composition of a household's portfolio, such as taxes, house price changes and life-cycle effects. For instance, our model predicts that households in the bottom 40 percent of the wealth distribution hold, on average, 339 percent of their wealth as houses, whereas this number is 280 percent in the data. For the top quintile, the predicted ratio in the model is 24 , while it is 27 in the data.

Next, Table 4 presents wealth distribution statistics for the one-asset economy. In this case, we cannot distinguish between financial assets and houses and concentrate on total wealth. The Gini index for wealth is slightly lower in the benchmark economy than in the one-asset economy, 0.801 and 0.816 , respectively. Inequality is lower in the benchmark economy (which does not allow for a rental market) because all households have some wealth in the form of the required down payment. The difference between both economies is small because the frictions of our model (down payments and adjustment costs) mainly affect the poor who only account for a small fraction of aggregate wealth. In the one-asset economy, both the down payment and the adjustment cost are zero (as opposed to 20 and 5 percent,respectively, in the benchmark case). That is, there is more credit and more liquidity in the one-asset economy than in the benchmark economy. Lowering the down payment only affects households who are constrained at the margin, typically poor households. Moreover, the larger the house a individual owns, the higher the possible loan. That is, collateralized

\footnotetext{
${ }^{12}$ Since financial assets may be negative, the reported Gini index is corrected following Chen, Tsaur, and Rhai (1982) and still between 0 and 1.
} 
loans of this type provide more credit to households who may need it less. In addition, wealthy households do not need to change their houses as often as less wealthy ones, the reason being that the variance of their income is lower than that of poor households because earnings represent a lower fraction of their income.

Aside from houses being illiquid, we have made two assumptions that may be important for understanding the differences between the benchmark economy and the one-asset economy. The first is the absence of a housing rental market. The second is the minimum house size that a household can purchase. We analyze each in turn.

\subsection{The role of the housing rental market}

In our benchmark economy, houses have a very similar distribution to that of earnings. In the data, however, houses are much more concentrated. In the model, the Gini indices for earnings and houses are 0.499 and 0.483 , respectively, whereas in the data they are 0.497 and 0.649 (compare Table 4 and Table 1). This discrepancy may be explained by the fact that we are abstracting from a housing rental market. Thus, the question we address here is whether the existence of a rental market has an impact on the level of wealth inequality.

To investigate this possibility, we consider an alternative economy with an explicit rental market. Households can obtain housing services either by purchasing them in the market or by buying housing stock. We proceed as in Gervais (2002) and assume there is a financial intermediary that buys housing stock and sells housing services in the market. Our main simplification is that the financial intermediary is not subject to adjustment costs when transacting the housing stock. As commonly used in the tenure choice literature (see Henderson and Ioannides 1983), we assume rental units depreciate at a higher rate than owner-occupied units to capture possible moral hazard problems in the rental market. We have labeled this economy the choice economy (we provide a more detailed description, as well as an equilibrium concept in Appendix B). Importantly, the economy is calibrated so that it produces the same aggregates as both the one-asset and the benchmark economy (parameters shown in Table 3). When calibrating the model we have one extra target, the homeownership rate (roughly 69 percent in the U.S.) and one more parameter, the additional depreciation of rental units, $\delta^{f}$. An incremental depreciation of 0.6 percent allows us to obtain our target. The bottom panel of Table 4 presents the comparable wealth distribution measures.

Without a rental market, all households must buy some housing stock. Therefore, they are 
forced to keep some savings in the form of the required down payment. However, this wealth is illiquid. Since poor households face more fluctuations in their income than relatively rich households (uncertain earnings are a higher proportion of total income for them), they feel more compelled to build a buffer stock of liquid assets to smooth their nondurable consumption. With a rental market, poor households can rent instead instead of owning a house and they do not need to accumulate extra savings, and as a result, wealth inequality is slightly higher than in the one-asset economy (the Gini index for total wealth increases from 0.801 to 0.809 ). The effect on total wealth inequality is small because the introduction of the rental market affects mainly the poor who account for just a small fraction of total wealth. However, the effect on the distribution of houses is significant. The Gini coefficient for houses rises from 0.483 to 0.585 , closer to the number in the data, 0.649. In summary, inequality in houses substantially increases when a rental market is introduced but the overall level of wealth inequality rises just slightly.

\subsection{The role of the minimum house size}

In our computation strategy so far, we have not imposed any minimum house size available to consumers. Households can buy or rent whatever size house they desire. In absence of a rental market, imposing a minimum size for the houses individuals can purchase would produce a lower wealth inequality than in the benchmark economy. Without a rental market, households are forced to save more to accumulate the down payment if the house they must purchase is bigger. Poor households, who are most likely affected, have to increase their savings proportionally more than wealthier ones. Also, by increasing the minimum size we are compressing the variance of the housing distribution. As a result, wealth inequality must be lower.

In the choice economy, however, the result would be the opposite. The larger the smallest house available, the higher the earnings of the household who is indifferent between renting and buying, and the higher the fraction of households who rent. Therefore, the fraction of households whose portfolio return is equal to the interest rate is higher, and wealth inequality must be larger the larger the house minimum size. Nevertheless, inequality is never larger than in the one-asset economy, the case in which all households get the same portfolio return. The reason is the following. Consider the extreme case in which the minimum house size is so large that all households rent (and the economy is calibrated to produce the same aggregates). Further, assume that there is no moral hazard problems (i.e., the depreciation rate of owner occupied units and rental units is the same). In this economy, housing services are produced by a financial intermediary and households 
only hold liquid financial assets. The financial intermediary decides what proportion of financial assets is rented out to the firm as capital and what proportion is sold to household as housing services (in equilibrium both returns are the same). In the one-asset economy, a household's wealth is composed of financial assets and houses but both are equally liquid so the two economies are equivalent. This can be seen by comparing the second and fourth panels in Table 4: the one-asset economy and the high minimum size economy just described produce identical distributions. ${ }^{13}$

\subsection{The role of superstars}

Our calibration of the persistence of the superstar shock is guided by the Gini index for wealth we want to match. However, we cannot estimate this persistence from standard data sets. This is not the case for the process governing regular households' shocks, which is very close to the idiosyncratic component of the earnings process estimated by Storesletten, Telmer, and Yaron (2004) using data from the PSID. What is the contribution of superstars in shaping the overall level of wealth inequality? To answer this question, we eliminate the superstar shock and recalibrate all economies so that they still produce the same aggregates. The results are shown in Table 5.

The Gini index for wealth falls to 0.645 , whereas in the benchmark economy with superstars the Gini index for regular households is 0.75 (its counterpart in the data is 0.77 , see Table 1). Importantly, wealth inequality is slightly lower in the benchmark economy than in the one-asset economy and the difference in the Gini indices is about the same magnitude as in the specification with superstars. Thus, adding the superstars not only helps us bring the overall Gini coefficient for wealth closer to that of the data, but it also helps us obtain the implied level of wealth inequality for households outside the top 1 percent of the earnings distribution. Eliminating superstars, however, does not change our main result: the existence of illiquid assets and credit frictions mitigate somewhat the effect of uninsurable idiosyncratic labor risk on wealth inequality resulting in slightly lower inequality.

\subsection{The role of the persistence of the earnings process}

Our benchmark model with illiquid assets and credit frictions delivers just slightly lower wealth inequality than the standard one-asset economy used in the literature. This result is obtained using an earnings process with very high persistence (consistent with the empirical evidence). To

\footnotetext{
${ }^{13}$ The small differences in the second decimal point for the quintiles are due to numerical error. In our computations of the economy with a high minimum size, we set the smallest house size to be 8 times the highest earnings shock.
} 
determine if our result is robust to this specification, we simulate our model economy using a different transition matrix for the earnings process holding the earnings shocks and the stationary distribution constant. In particular, we keep the probability of becoming a superstar unchanged but assume the probability of being one of the six regular types is the same for all types. The transition matrix is shown in Table 6 . We recalibrate the relevant parameters so that aggregate statistics remain the same (the parameter values are in the notes to Table 7). We call this economy the volatile benchmark economy.

With lower persistence in the earnings process, wealth inequality is much lower than before (the Gini index is 0.635 in the volatile bechmark case). Houses are more equally distributed (the Gini coefficient is 0.256 ) and financial assets are less concentrated (the Gini coefficient is 0.863). Housing wealth as a fraction of total wealth decreases in all quintiles - since earnings shocks are not persistent, households accumulate proportionally more liquid assets. As with the persistent earnings process, housing wealth as a fraction of total wealth decreases with wealth but the differences across quintiles are less extreme. In the one-asset economy, wealth is also less concentrated (the Gini index is 0.676 ). Importantly, inequality is still higher in the volatile one-asset economy than in the volatile benchmark economy. Moreover, the difference is now more pronounced. In order to understand why this is the case, it is useful to construct a measure of permanent earnings in our model.

Since we abstract from aggregate uncertainty, for any household whose earnings shock in period $t$ is $e$, we can write permanent earnings, $\widehat{e}$, as the sum of current and future earnings:

$$
\widehat{e}=E_{t}\left\{w \sum_{s=t}^{\infty}\left(\frac{1}{1+r}\right)^{s-t} e_{s}\right\}=w\left(e+\frac{1}{1+r} \sum_{e^{\prime}} \pi_{e, e^{\prime}} \widehat{e^{\prime}}\right)
$$

The (normalized) permanent earnings shocks with the volatile process and the original process are: $\{1.00,1.01,1.01,1.02,1.04,1.09,7.38\}$ and $\{1.00,1.22,1.49,1.84,2.32,3.04,13.07\}$, respectively. Regular households are much more similar with the more volatile earnings process, they save less, which leads to lower inequality. For the same reason, houses are more similar across households, which results in less differences in wealth composition across quintiles. Furthermore, with less savings, more households are likely to be affected by the frictions of our model, which explains the larger difference in inequality between the benchmark economy and the one-asset economy in this case. However, the difference in wealth inequality across models is still modest in magnitude.

This calibration allows us to illustrate further the predictions of our model regarding the distribution of houses. Table 8 presents key distributional statistics for homeowners in the data (first 
panel) and in the model with both persistent and volatile earnings (second panel and third panels respectively). With persistent earnings, the Gini index for earnings is lower in the model than in the data (0.408 vs. 0.479 in the data). This implies lower levels of inequality for any dimension of wealth but, nevertheless, the model with persistent earnings captures the remarkable similarity of the distributions of earnings and houses observed in the data. This feature of the data is not specific to 1998 as shown in Table 9 (although houses are becoming slightly more concentrated than earnings in the recent years). In our model, houses cannot be more unequally distributed than earnings for homeowners because the return to owner occupied housing falls with the size of the house. Note that with volatile earnings, the Gini coefficient for houses is less than half the coefficient for earnings (0.179 vs. 0.449). ${ }^{14}$ What causes this difference? The distributions of earnings and houses are quite close with persistent earnings in our model because permanent earnings and current earnings are highly correlated and households acquire houses according to their permanent income. ${ }^{15}$ While permanent income still guides house purchases with volatile earnings, current earnings in this case are not highly correlated with permanent income and the distributions are not alike.

In summary, high persistence is necessary to obtain a Gini index for wealth close to the one observed in the data. Nevertheless, earnings persistence cannot be estimated directly using the Survey of Consumer Finances. ${ }^{16}$ Our analysis in this section suggests that the distribution of houses might be used to discriminate among earnings processes that differ in their persistence. That is, the distribution of houses gives us indirect evidence of the persistence of the earnings process.

\section{Changes in the down payment and the adjustment cost}

Over the last few decades, there has been a significant reduction in the down payment required by financial institutions as well as a proliferation of home equity loans. In our model, a decrease in the parameter $\theta$ captures these financial changes (although we cannot disentangle one from the other). We analyze the effects of financial liberalization on aggregate ratios and on the wealth distribution

\footnotetext{
${ }^{14}$ Interestingly, inequality in earnings for homeowners is higher with volatile earnings than with persistent earnings. This is because the homeownership rate increases for the lower quintiles. Refer to the row labeled 'Homeowners by $E$, \%' in Table 7.

${ }^{15}$ In the case in which households are liquidity constrained the correlation between houses and earnings should be stronger regardless of the persistence of the earnings process.

${ }^{16}$ See Castañeda, Díaz-Giménez, and Ríos-Rull (2003) and Storesletten, Telmer, and Yaron (2004) for a discussion about the problems of the methods used to estimate the persistence of the earnings process using data.
} 
by simulating our model economy for different values of the down payment requirement (keeping all other parameters constant).

A decrease in the down payment requirement relaxes the borrowing constraint. Thus, fewer households are constrained and their purchases of houses increase. Therefore, inequality in houses should decrease (see Table 10). However, because a decrease in $\theta$ implies higher borrowing in the economy, financial assets become more concentrated and overall, wealth inequality worsens. In general, the observed effects tend to be small. This is because changes in the down payment affect mainly liquidity constrained households, who are concentrated at the bottom of the wealth distribution. Since their asset holdings amount to a very small fraction of aggregate wealth, the effect of changing the down payment on total wealth is not large. For instance, the Gini of wealth with no down payment is 0.81 , while with a 20 percent down payment it is 0.801 . When the down payment is 100 percent, the Gini coefficient for wealth is substantially lower, 0.736. Table 10 demonstrates that the distribution of financial assets across quintiles is significantly more concentrated for lower down payments. The counterpart to this result is in Table 11, where we show that the portfolio of poor households becomes substantially more illiquid as down payments fall. Table 11 also indicates that with lower down payments, the housing stock increases, the capital stock decreases and the interest rate rises (from 3.473 for a 100 percent down payment to 3.996 for no down payment).

With a rental market, as down payments decrease, homeownership increases (results not tabulated for brevity). For example, with a down payment of 50 percent, homeownership is only 49 percent, while with a 5 percent down payment the rate is 83 percent. As a result, inequality in housing decreases considerably more than without a rental market (the corresponding Gini coefficients for housing for a 50 percent and a 5 percent down payment are 0.68 and 0.55 respectively). As before, because there is more borrowing, financial assets become more concentrated with lower down payments. The effect on overall inequality is even smaller in this case and can be non-monotonic in the down payment. For example, going from a 50 percent to a 20 percent down payment leads to less inequality (the Gini index for wealth goes from 0.8116 to 0.809 ), while going from a 20 percent to a 5 percent down payment increases inequality slightly (the Gini index increases from 0.809 to 0.8121). However, with or without a rental market, when down payments decrease the housing stock increases, the capital stock decreases and the interest rate rises (the equilibrium interest rate in the choice economy with a 50 percent down payment is 3.87 percent while the interest rate is 3.95 percent with a 5 percent down payment).

We also investigate the effect of changes in the degree of illiquidity of houses. In Table 10, we 
report aggregates with a higher adjustment cost, with no adjustment costs and for an economy with liquid houses and no down payments $(\rho=0, \theta=0)$. As before, all remaining parameters are kept at their benchmark values. For a given down payment, lowering $\rho$ makes the durable more attractive for households of all wealth levels, which leads to an important increase in the housing stock. Thus, the change in aggregate wealth composition seems more dramatic than the effect of lowering down payments. Since the housing stock increases, the capital stock decreases and the interest rate sharply rises (from 3.71 to 4.25 when going from 10 percent to 0 percent in transaction costs). However, the effect on the wealth distribution is negligible. In terms of wealth composition (see Table 11), decreasing the degree of illiquidity increases the housing wealth to total wealth ratio substantially for the lower quintiles.

\section{Final comments}

In this paper, we explicitly model the existence of illiquid houses that serve as collateral for loans in the context of a heterogenous agents model with uninsurable earnings risk. Our goal is to asses whether the availability of houses mitigates the effect of uninsurable idiosyncratic labor risk on wealth inequality. In our model, households can save in the form of a liquid asset and in the form of illiquid houses that can be purchased on credit (minus a down payment). Our economy delivers slightly less wealth inequality than the one-asset economy analyzed in the literature. We show that the standard model is indeed equivalent to an economy with liquid houses, a zero down payment and a perfect rental market. The difference in terms of wealth inequality between both economies is small because the frictions of our model (required down payments and adjustment costs) mainly affect the poor who only account for a small fraction of aggregate wealth.

Importantly, our two-asset economy has one main advantage over the standard one-asset framework: it allows us to study wealth composition issues. Our model is able to reproduce all main patterns of the U.S. distribution: (1) wealth is more concentrated than earnings, (2) financial assets are more concentrated than wealth, (3) households' portfolios become more liquid as wealth increases, and (4) the distribution of houses and earnings for homeowners are very similar. A fairly persistent earnings process is necessary to obtain the latter result. We also show that the easing of collateral credit has an important effect on the portfolios of the relatively poor.

In this study, we abstract from some important issues that remain topics for future research. The most obvious and potentially important one, is the omission of life-cycle effects. In the data, 
a household's portfolio composition varies with age and it would be interesting to analyze whether or not the model can account for the life-cycle patterns of wealth holding and wealth composition. Also, some of the aggregate effects discussed in this paper may be amplified when including life cycle considerations. An further extension could deal with the interaction between collateral credit and earnings ability. For example, access to collateral credit could increase the probability of becoming a superstar. ${ }^{17}$

\section{Appendices}

\section{A The one-asset economy}

\section{A.1 The household's problem}

A household derives utility from consumption of a nondurable good, $c$, and housing services obtained through the rental market, $s$. The price per unit of housing services is $i$. Households may hold both financial assets, $a$, and residential assets, $h$. The stock of houses $h$ is liquid and can be fully financed.

$$
\begin{array}{ll}
v(e, a, h)= & \max _{\substack{c \geq 0, a^{\prime} \\
h^{\prime} \geq 0, s \geq 0}} u(c, s)+\beta \sum_{e^{\prime}} \pi_{e, e^{\prime}} v\left(e^{\prime}, a^{\prime}, h^{\prime}\right) \\
& c+a^{\prime}+h^{\prime}-\left(1-\delta^{h}\right) h+i s=w e+(1+r) a+i h, \\
& a^{\prime}+h^{\prime} \geq 0 .
\end{array}
$$

\section{A.2 Definition of equilibrium}

A steady state equilibrium for this economy is a set of functions for the household problem $\left\{v(x), g^{a}(x), g^{h}(x), g^{c}(x), g^{s}(x)\right\}$, and a measure of households, $\mu$, such that:

1. The durable rental market clears: $S=\int_{X} g^{s}(x) d \mu=\int_{X} h d \mu$.

2. Factor inputs are: $K=\int_{X} g^{a}(x) d \mu$ and $L=\int_{X} e d \mu$.

3. Factor rental prices are factor marginal productivities: $r=F_{1}(K, L)-\delta^{k}$ and $w=F_{2}(K, L)$.

4. The housing rental price satisfies $i-\delta^{h}=r$.

\footnotetext{
${ }^{17}$ Becoming a superstar may require some innate ability plus an initial investment.
} 
5. Given $\mu, K, L$ and $H$, the functions $\left\{v(x), g^{a}(x), g^{h}(x), g^{c}(x), g^{s}(x)\right\}$ solve the household's decision problem.

6. The markets for capital, nondurable consumption and houses clear: $\int_{X}\left[g^{a}(x)-\left(1-\delta^{k}\right) a\right] d \mu=$ $I_{k}, \int_{X} g^{c}(x) d \mu=C, \int_{X}\left[g^{h}(x)-\left(1-\delta^{h}\right) h\right] d \mu=I_{h}$.

7. The feasibility constraint is satisfied: $C+I_{k}+I_{h}=F(K, L)$.

8. The measure of households is stationary: $x(B)=\int_{X} P(x, B) d \mu$, for all $B \subset \mathcal{B}$.

\section{A.3 Computation of the Equilibrium}

Since in this case households only care about total assets and the portfolio composition cannot be determined, we assume, without loss of generality, that all housing services are acquired through the rental market and that households hold a single asset, $b=a+h$. The household problem that we actually solve when computing the equilibrium is:

$$
\begin{array}{ll}
v(e, b)= & \max _{c \geq 0, s \geq 0, b^{\prime}} u(c, s)+\beta \sum_{e^{\prime}} \pi_{e, e^{\prime}} v\left(e^{\prime}, b^{\prime}\right) \\
\text { s.t. } & c+b^{\prime}+i s=w e+(1+r) b, \\
& b^{\prime} \geq 0 .
\end{array}
$$

A steady state equilibrium for this economy is a set of functions for the household problem $\left\{v(x), g^{b}(x), g^{c}(x), g^{s}(x)\right\}$, and a measure of households, $\mu$, such that:

1. Factor inputs are: $K=\int_{X}\left[g^{b}(x)-g^{s}(x)\right] d \mu$ and $L=\int_{X} e d \mu$.

2. Factor rental prices are factor marginal productivities: $r=F_{1}(K, L)-\delta^{k}$ and $w=F_{2}(K, L)$.

3. The housing rental price satisfies $i-\delta^{h}=r$.

4. The durable rental market clears: $S=\int_{X} g^{s}(x) d \mu=H$.

5. Given $\mu, K, L$ and $H$, the functions $\left\{v(x), g^{b}(x), g^{c}(x), g^{s}(x)\right\}$ solve the household's decision problem.

6. The markets for nondurable consumption, houses, and capital clear: $\int_{X} g^{c}(x) d \mu=C$, $\int_{X}\left[g^{s}(x)-\left(1-\delta^{h}\right) s\right] d \mu=I_{h}, \int_{X}\left[\left(g^{b}(x)-g^{s}(x)\right)-\left(1-\delta^{k}\right)(b-s)\right] d \mu=I_{k}$.

7. The feasibility constraint is satisfied: $C+I_{k}+I_{h}=F(K, L)$. 
8. The measure of households is stationary: $x(B)=\int_{X} P(x, B) d \mu$, for all $B \subset \mathcal{B}$.

\section{B An economy with a housing rental market}

\section{B.1 The household's problem}

A household derives utility from consumption of a nondurable good, $c$, and housing services. Housing services can be acquired in the market or through homeownership. The price per unit of housing services is $i$. $f$ denotes housing services acquired through the rental market. We assume households cannot be renters and homeowners at the same time. Households may hold both financial assets, $a$, and residential assets, $h$. The stock of houses $h$ is illiquid and cannot be fully financed.

$$
\begin{array}{ll}
v(e, a, h)= & \max _{\substack{c \geq 0, a^{\prime} \geq 0 \\
z \in\{0,1\} \\
h^{\prime} \geq 0}} u(c, s)+\beta \sum_{e^{\prime}} \pi_{e, e^{\prime}} v\left(e^{\prime}, a^{\prime}, d^{\prime}\right) \\
& c+i f+a^{\prime}+h^{\prime}-\left(1-\delta^{h}\right) h+\tau\left(h^{\prime}, h\right)=w e+(1+r) a \\
\text { s.t. } & s=(1-z) f+z h^{\prime}, \\
& a^{\prime}+(1-\theta) h^{\prime} \geq 0 .
\end{array}
$$

\section{B.2 The firm's problem}

The representative firm solves the following static problem:

$$
\max _{K_{t}, L_{t}} F\left(K_{t}, L_{t}\right)-\left(r+\delta^{k}\right) K_{t}-w L_{t}
$$

where $L_{t}$ denotes aggregate labor, $r$ is the rental price of capital net of depreciation and $w$ is the wage per efficiency unit of labor.

\section{B.3 The financial institution's problem}

The financial institution receives financial assets from households and rents capital to firms and residential services to households. We allow rental units to have a different depreciation rate than 
owner occupied housing. The financial institution solves the following problem:

$$
\begin{aligned}
\Psi(A)= & \max _{A^{\prime}, K, F}\left\{A^{\prime}-(1+r) A+r K+\left(i-\delta^{f}\right) F+\frac{1}{1+r} \Psi\left(A^{\prime}\right)\right\} \\
& \text { s. t. } K+F \leq A,
\end{aligned}
$$

where $F$ is the stock of rental units and $i$ is the rental price.

\section{B.4 Equilibrium}

A steady state equilibrium for this economy is a set of functions for the household problem $\left\{v(x), g^{a}(x), g^{h}(x), g^{c}(x), g^{f}(x)\right\}$, and a measure of households, $\mu$, such that:

1. Total labor services are obtained aggregating across households, $L=\int_{X} e d \mu$.

2. Total financial assets equal $A=\int_{X} g^{a}(x) d \mu$.

3. The rental market for housing clears, $F=\int_{X} g^{f}(x) d \mu$.

4. The aggregate capital stock is $K=A-F$.

5. Factor rental prices are factor marginal productivities, $r=F_{1}(K, L)-\delta^{k}$, and $w=F_{2}(K, L)$.

6. The rental price of housing satisfies $i=r+\delta^{f}$.

7. Given $\mu$, and $r$ the functions $\left\{v, g^{a}, g^{h}, g^{f}, g^{c}\right\}$ solve the household's problem in (13).

8. The market for the final good clears: $I_{h}=\delta^{f} F+\int_{X}\left[g^{h}(x)-\left(1-\delta^{h}\right) h+\tau\left(g^{h}(x), h\right)\right] d \mu$.

9. The feasibility constraint is satisfied: $C=\int_{X} g^{c}(x) d \mu, C+\delta^{k} K+I_{h}=F(K, L)$.

10. The measure of households is stationary: $x(B)=\int_{X} Q(x, B) d \mu$, for all $B \subset \mathcal{B}$.

\section{Computational Procedures}

In order to compute the equilibrium of our benchmark model, it is convenient to reformulate the household problem. Define voluntary equity as the wealth held in excess of the required down payment, $q \equiv a+(1-\theta) h$. The state variables for the household problem are the earnings shock, voluntary equity, and the housing stock, $\{e, q, h\}$. With this reformulation, we deal with two assets 
whose values are restricted to be non-negative. This greatly simplifies the problem imposed by the endogenous liquidity constraint in the solution of the household problem.

Let $Q$ be aggregate voluntary equity. Feasibility becomes:

$$
C+Q^{\prime}-\left(1-\delta_{k}\right) Q+\theta H^{\prime}+\left[\left(1-\delta_{k}\right)(1-\theta)-\left(1-\delta_{h}\right)(1-I \rho)\right] H=F(Q-(1-\theta) H, L) .
$$

Factor prices can easily be written in terms of $Q$ and $H$. The household problem can be rewritten as follows:

$$
v(e, q, h)=\max _{q^{\prime} \geq 0, h^{\prime} \geq 0}\left\{u(c, h)+\beta \sum_{e^{\prime}} \pi_{e, e^{\prime}} v\left(e^{\prime}, q^{\prime}, h^{\prime}\right)\right\},
$$

where

$$
c=w e+(1+r) q+\left[\left(1-\delta^{h}\right)(1-I \rho)-(1-\theta)(1+r)\right] h-q^{\prime}-\theta h^{\prime} .
$$

Because of the non-convex adjustment cost, we use a finite state approximation approach to solve the household problem. The technique consists of specifying a finite-state (discrete) problem that approximates the continuous one we want to solve. With our reformulation, today's controls are next period's states and the grids for both assets start at zero. The upper values for the grids must be chosen with care by trial and error. We solve the problem by value function iteration. We guess an initial value function and make agents choose next period's values of $q^{\prime}$ and $h^{\prime}$ in the grid. Choosing values of the policy function in a two-dimensional grid can be computationally very costly. We use a policy function accelerator described in Judd (1998) to speed up convergence. To compute the steady state of the model we use standard procedures.

For the results reported in this paper we use 300 hundred grid points for voluntary equity and 100 points for the housing stock (the grid points are not equally space to maximize efficiency). With 7 exogenous earnings shocks, this implies solving the household's problem for 210,000 points at each iteration. To verify that our results are robust to the density of the grids, we solve a few specifications with twice as many points for each asset (600 for voluntary equity and 200 for housing; solving the household problem once takes approximately 37 hours in an Intel Core 2 duo R6600 processor). Table 12 presents wealth distribution statistics equivalent to those in Table 4 for the benchmark case. The Gini coefficients and quintiles are extremely similar in both cases (the differences for the Gini indices are at the third decimal place). Of course, parameter values have 
to be adjusted to obtain the same aggregates with more points. The changes, however, are again minimal $\left(\delta^{h}=0.365\right.$ with more points vs. 0.367 with fewer points; $\beta=0.9003$ with more points vs. $\beta=0.9006$ with fewer points). Since the differences are not very significant, we proceeded with fewer grid points to save computational time. 
Table 1: Selected data from the 1998 Survey of Consumer Finances

\begin{tabular}{|c|c|c|c|c|c|c|}
\hline \multicolumn{7}{|c|}{ HOUSEHOLDS WITH POSITIVE EARNINGS } \\
\hline & \multicolumn{5}{|c|}{$\begin{array}{c}\text { Quintiles } \\
\end{array}$} & \multirow{2}{*}{$\begin{array}{l}\text { Gini } \\
\text { coeff. }\end{array}$} \\
\hline & 1 st & 2nd & 3rd & 4 th & 5 th & \\
\hline Earnings, $E$ & 3.26 & 8.71 & 14.08 & 21.09 & 52.83 & 0.497 \\
\hline Houses, $H$ & 0.00 & 1.60 & 12.67 & 22.27 & 63.45 & 0.649 \\
\hline Financial assets, $A$ & -8.52 & -0.79 & 0.96 & 6.33 & 101.97 & 0.945 \\
\hline Wealth, $W$ & -0.33 & 1.36 & 4.85 & 11.81 & 82.27 & \multirow[t]{4}{*}{0.804} \\
\hline$H / W_{(1)}$ & \multicolumn{2}{|c|}{280.89} & 113.27 & 73.16 & 26.76 & \\
\hline$H / W_{(2)}$ & 4260.07 & 313.40 & 137.88 & 82.38 & 46.71 & \\
\hline Homeowners by $\mathrm{E} \%$ & 46.56 & 52.28 & 69.06 & 83.62 & 91.72 & \\
\hline \multirow[t]{3}{*}{ HOUSEHOLDS WITH $\mathrm{H}$} & OSITIVE & ARNING & WITHO & T THE & TOP $1 \%$ & EARN. \\
\hline & \multicolumn{5}{|c|}{ Quintiles } & Gini \\
\hline & $1 \mathrm{st}$ & 2nd & $3 \mathrm{rd}$ & 4 th & 5 th & coeff. \\
\hline Earnings, $E$ & 3.71 & 9.91 & 15.94 & 23.81 & 46.62 & 0.432 \\
\hline Houses, $H$ & 0.00 & 1.60 & 13.35 & 23.40 & 61.65 & 0.634 \\
\hline Financial assets, $A$ & -11.72 & -1.13 & 1.25 & 8.13 & 103.43 & 0.941 \\
\hline Wealth, $W$ & -0.42 & 1.64 & 5.84 & 14.08 & 78.84 & 0.771 \\
\hline$H / W_{(1)}$ & \multicolumn{2}{|c|}{290.25} & 114.29 & 74.70 & 30.77 & \\
\hline$H / W_{(2)}$ & 4399.67 & 318.54 & 139.82 & 83.48 & 47.97 & \\
\hline Homeowners by $\mathrm{E} \%$ & 46.43 & 52.16 & 68.44 & 83.15 & 91.72 & \\
\hline \multicolumn{7}{|c|}{ All HouseHOLDS } \\
\hline & \multicolumn{5}{|c|}{ Quintiles } & Gini \\
\hline & 1 st & 2nd & $3 \mathrm{rd}$ & 4 th & 5 th & coeff. \\
\hline Earnings, $E$ & -0.16 & 4.19 & 13.06 & 22.93 & 59.98 & 0.606 \\
\hline Houses, $H$ & 0.00 & 1.40 & 12.31 & 22.08 & 64.21 & 0.656 \\
\hline Financial assets, $A$ & -7.27 & -0.25 & 1.14 & 6.92 & 99.45 & 0.953 \\
\hline Wealth, $W$ & -0.29 & 1.35 & 5.14 & 12.38 & 81.42 & 0.796 \\
\hline$H / W_{(1)}$ & \multicolumn{2}{|c|}{237.60} & 103.83 & 69.68 & 26.97 & \\
\hline$H / W_{(2)}$ & 4381.90 & 289.26 & 124.78 & 77.13 & 45.89 & \\
\hline Homeowners by E \% & 65.40 & 48.44 & 58.70 & 75.87 & 91.51 & \\
\hline
\end{tabular}

Notes: Households are ordered by the variable indicated in each row, except for the rows labeled ' $H / W$ ' in which households are ordered by total wealth, $W$. (1): Sum of housing wealth in the quintile divided by total wealth in the quintile. (2): The mean housing wealth to total wealth ratio in the quintile. 
Table 2: The earnings process

\begin{tabular}{ccccccc}
\hline \hline \multicolumn{7}{c}{ The earnings shocks, $e$} \\
\hline 0.18 & 0.34 & 0.51 & 0.73 & 1.09 & 2.36 & 14.15 \\
\hline \hline 0.910833 & 0.088657 & 0.000010 & 0.000000 & 0.000000 & 0.000000 & 0.0005 \\
0.088657 & 0.781730 & 0.128927 & 0.000186 & 0.000000 & 0.000000 & 0.0005 \\
0.000010 & 0.128927 & 0.729050 & 0.141327 & 0.000186 & 0.000000 & 0.0005 \\
0.000000 & 0.000186 & 0.141327 & 0.729050 & 0.128927 & 0.000010 & 0.0005 \\
0.000000 & 0.000000 & 0.000186 & 0.128927 & 0.781730 & 0.088657 & 0.0005 \\
0.000000 & 0.000000 & 0.000000 & 0.000010 & 0.088657 & 0.910833 & 0.0005 \\
0.008250 & 0.008250 & 0.008250 & 0.008250 & 0.008250 & 0.008250 & 0.9505 \\
\hline \hline \multicolumn{7}{c}{ Stationary distribution, $\pi^{*}$} \\
\hline 0.165 & 0.165 & 0.165 & 0.165 & 0.165 \\
\hline \multicolumn{7}{c}{}
\end{tabular}

Table 3: Parameters

\begin{tabular}{|c|c|c|c|c|c|c|c|c|c|}
\hline & \multicolumn{4}{|c|}{ Technology } & \multicolumn{2}{|c|}{ Finan. arrang. } & \multicolumn{3}{|c|}{ Utility } \\
\hline & $\alpha$ & $\delta^{k}$ & $\delta^{h}$ & $\delta^{f}$ & $\theta$ & $\rho$ & $\beta$ & $\sigma$ & $\gamma$ \\
\hline Benchmark & 0.255 & 0.117 & 0.037 & - & 0.2 & 0.05 & 0.901 & 2 & 0.166 \\
\hline One asset & 0.255 & 0.117 & 0.043 & 0.000 & 0.0 & 0.00 & 0.904 & 2 & 0.161 \\
\hline Choice & 0.255 & 0.117 & 0.042 & 0.006 & 0.2 & 0.05 & 0.901 & 2 & 0.176 \\
\hline High min. size & 0.255 & 0.117 & 0.043 & 0.000 & 0.2 & 0.05 & 0.904 & 2 & 0.161 \\
\hline
\end{tabular}

Notes: $\alpha$ is the capital share, $\delta^{k}$ and $\delta^{h}$ are the depreciation rates for capital and owner-occupied houses respectively. $\delta^{f}$ is the additional depreciation rate for rental units. $\theta$ and $\rho$ are the down payment and the adjustment cost parameter respectively. $\beta$ is the discount factor, $\sigma$ measures risk aversion and $\gamma$ is the parameter in the utility function that weights the importance of housing relative to nondurable consumption. 
Table 4: The wealth distribution

\begin{tabular}{|c|c|c|c|c|c|c|}
\hline & \multicolumn{5}{|c|}{ Quintiles \% } & \multirow{2}{*}{$\begin{array}{l}\text { Gini } \\
\text { index }\end{array}$} \\
\hline & $1 \mathrm{st}$ & 2nd & 3rd & 4 th & 5 th & \\
\hline Earnings & 4.18 & 7.99 & 12.57 & 19.64 & 55.60 & 0.499 \\
\hline \multirow[t]{2}{*}{ Earnings without top $1 \%$} & 4.78 & 9.13 & 14.34 & 22.32 & 49.42 & 0.433 \\
\hline & \multicolumn{5}{|c|}{ BENCHMARK ECONOMY } & \\
\hline Houses & 4.06 & 7.88 & 13.47 & 23.63 & 50.95 & 0.483 \\
\hline Financial assets & -5.70 & -3.14 & -1.85 & 7.89 & 102.77 & 0.930 \\
\hline Wealth & 0.38 & 1.12 & 2.96 & 13.85 & 81.67 & 0.801 \\
\hline \multirow{3}{*}{$\begin{array}{l}\text { Wealth without top } 1 \% \\
H / W_{(1)} \\
H / W_{(2)}\end{array}$} & 0.48 & 1.42 & 3.69 & 16.92 & 77.47 & \multirow[t]{3}{*}{0.750} \\
\hline & \multicolumn{2}{|c|}{339.36} & 179.92 & 67.90 & 24.05 & \\
\hline & 459.35 & 310.71 & 194.06 & 76.37 & 33.73 & \\
\hline & \multicolumn{5}{|c|}{ ONE-ASSET ECONOMY } & \\
\hline Wealth & 0.09 & 0.67 & 2.52 & 14.10 & 82.61 & 0.816 \\
\hline \multirow[t]{2}{*}{ Wealth without top $1 \%$} & 0.11 & 0.85 & 3.10 & 17.26 & 78.68 & 0.770 \\
\hline & \multicolumn{5}{|c|}{ ChOICE } & \\
\hline Houses & 0.00 & 4.19 & 14.30 & 25.11 & 56.41 & 0.585 \\
\hline Financial assets & -4.74 & -1.20 & 0.36 & 8.63 & 96.95 & 0.911 \\
\hline Wealth & 0.08 & 0.86 & 2.98 & 13.99 & 82.09 & 0.809 \\
\hline Wealth without top $1 \%$ & 0.09 & 1.08 & 3.70 & 17.05 & 78.06 & 0.761 \\
\hline$H / W_{(1)}$ & \multicolumn{2}{|c|}{222.40} & 173.04 & 60.53 & 22.49 & \\
\hline$H / W_{(2)}$ & 0.00 & 333.58 & 194.78 & 68.67 & 33.36 & \\
\hline \multirow[t]{2}{*}{ Homeowners by E. \% } & 18.38 & 54.80 & 84.98 & 97.29 & 91.20 & \\
\hline & \multicolumn{5}{|c|}{ HIGH MINIMUM SIZE ECONOMY } & \\
\hline Wealth & 0.09 & 0.68 & 2.53 & 14.12 & 82.57 & 0.816 \\
\hline Wealth without top $1 \%$ & 0.11 & 0.86 & 3.11 & 17.30 & 78.61 & 0.769 \\
\hline
\end{tabular}

Notes: Households are ordered by the variable indicated in each row, except for the rows labeled ' $H / W$ ' in which households are ordered by total wealth, $W$. (1): Sum of housing wealth in the quintile divided by total wealth in the quintile. (2): The mean housing wealth to total wealth ratio in the quintile. The rows labeled 'without top 1\%' do not include households on the top $1 \%$ of the earnings distribution.

There is no rental market in the benchmark economy. In the one-asset economy, there is a perfect rental market. In the choice economy, there is a rental market with moral hazard. In the high-minimum-size economy, there is a perfect rental market and the minimum house size for sale is so large that all households rent. All economies are calibrated so that they produce the same aggregates ratios $H / C, H / Y$ and $K / Y$. Parameters summarized in Table 3. 
Table 5: The wealth distribution without superstars

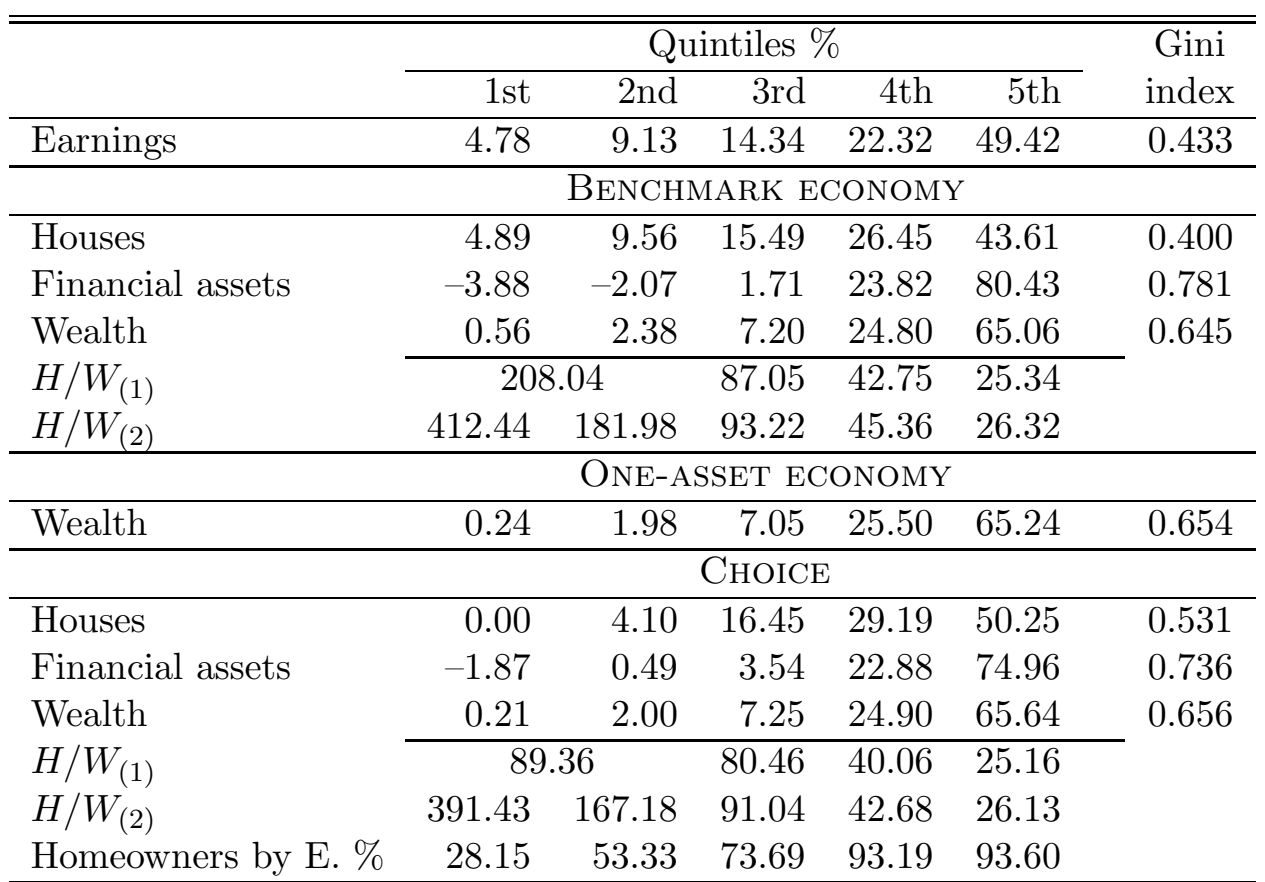

Notes: Households are ordered by the variable indicated in each row, except for the rows labeled ' $H / W$ ' in which households are ordered by total wealth, $W$. (1): Sum of housing wealth in the quintile divided by total wealth in the quintile. (2): The mean housing wealth to total wealth ratio in the quintile.

All economies are calibrated so that they produce the same aggregates ratios $H / C, H / Y$ and $K / Y . \alpha=0.255, \delta^{k}=0.117 \sigma=2$ in the three economies. In the one-asset economy, $\theta=0$ and $\rho=0$ vs. $\theta=0.2$ and $\rho=0.05$ in the other cases. $\beta$ is $0.915,0.916$ and 0.918 in benchmark, the choice and the one-asset economy respectively. $\gamma$ is $0.165,0.169$ and 0.161 , in the benchmark, the choice and the one-asset economy. $\delta^{h}$ is $0.037,0.04$ and 0.043 in benchmark, the choice and the one-asset economy respectively. $\delta^{f}=0.005$ in the choice economy and 0 in the one-asset economy.

Table 6: The volatile earnings process

\begin{tabular}{ccccccc}
\hline \hline \multicolumn{7}{c}{ The earnings shocks, $e$} \\
\hline 0.18 & 0.34 & 0.51 & 0.73 & 1.09 & 2.36 & 14.15 \\
\hline \hline 0.16658 & 0.16658 & 0.16658 & 0.16658 & 0.16658 & 0.16658 & 0.0005 \\
0.16658 & 0.16658 & 0.16658 & 0.16658 & 0.16658 & 0.16658 & 0.0005 \\
0.16658 & 0.16658 & 0.16658 & 0.16658 & 0.16658 & 0.16658 & 0.0005 \\
0.16658 & 0.16658 & 0.16658 & 0.16658 & 0.16658 & 0.16658 & 0.0005 \\
0.16658 & 0.16658 & 0.16658 & 0.16658 & 0.16658 & 0.16658 & 0.0005 \\
0.16658 & 0.16658 & 0.16658 & 0.16658 & 0.16658 & 0.16658 & 0.0005 \\
0.00825 & 0.00825 & 0.00825 & 0.00825 & 0.00825 & 0.00825 & 0.9505 \\
\hline \hline \multicolumn{7}{c}{ Stationary distribution, $\pi^{*}$} \\
\hline 0.165 & 0.165 & 0.165 & 0.165 & 0.165 & 0.165 & 0.010 \\
\hline
\end{tabular}


Table 7: The wealth distribution with volatile earnings

\begin{tabular}{|c|c|c|c|c|c|c|}
\hline & \multicolumn{5}{|c|}{ Quintiles \% } & \multirow{2}{*}{$\begin{array}{l}\text { Gini } \\
\text { index }\end{array}$} \\
\hline & 1 st & $2 \mathrm{nd}$ & $3 \mathrm{rd}$ & 4 th & 5th & \\
\hline \multirow[t]{2}{*}{ Earnings } & 4.18 & 7.99 & 12.57 & 19.64 & 55.60 & 0.499 \\
\hline & \multicolumn{5}{|c|}{ VOLATILE BENCHMARK ECONOMY } & \\
\hline Houses & 11.24 & 16.19 & 16.42 & 18.47 & 37.68 & \multirow{5}{*}{$\begin{array}{l}0.256 \\
0.863 \\
0.635\end{array}$} \\
\hline Financial assets & -4.32 & 0.02 & 5.81 & 12.65 & 85.84 & \\
\hline Wealth & 2.55 & 6.37 & 10.28 & 14.76 & 66.05 & \\
\hline$H / W_{(1)}$ & \multicolumn{2}{|c|}{127.81} & 65.75 & 48.55 & 21.41 & \\
\hline \multirow[t]{2}{*}{$H / W_{(2)}$} & 239.09 & 104.07 & 66.46 & 49.00 & 32.78 & \\
\hline & \multicolumn{5}{|c|}{ VOLATILE ONE-ASSET ECONOMY } & \\
\hline \multirow[t]{2}{*}{ Wealth } & 1.85 & 5.49 & 9.32 & 13.83 & 69.49 & 0.676 \\
\hline & \multicolumn{5}{|c|}{ Volatile Choice Economy } & \\
\hline Houses & 0.00 & 10.00 & 22.75 & 25.94 & 41.31 & \multirow{6}{*}{$\begin{array}{l}0.436 \\
0.796 \\
0.660\end{array}$} \\
\hline Financial assets & -1.33 & 2.90 & 6.80 & 11.78 & 79.85 & \\
\hline Wealth & 1.84 & 5.87 & 9.89 & 14.60 & 67.80 & \\
\hline$H / W_{(1)}$ & \multicolumn{2}{|c|}{66.64} & 55.39 & 49.36 & 16.66 & \\
\hline$H / W_{(2)}$ & 214.97 & 121.27 & 72.07 & 50.47 & 32.53 & \\
\hline Homeowners by E. $\%$ & 63.57 & 65.91 & 67.48 & 71.00 & 76.95 & \\
\hline
\end{tabular}

Notes: Households are ordered by the variable indicated in each row, except for the rows labeled ' $H / W$ ' in which households are ordered by total wealth, $W$. (1): Sum of housing wealth in the quintile divided by total wealth in the quintile. (2): The mean housing wealth to total wealth ratio in the quintile.

All economies are calibrated so that they produce the same aggregates ratios $H / C, H / Y$ and $K / Y . \alpha=0.255, \delta^{k}=0.117 \sigma=2$ in the three economies. In the one-asset economy, $\theta=0$ and $\rho=0$ vs. $\theta=0.2$ and $\rho=0.05$ in the other cases. $\beta$ is $0.903,0.906$ and 0.909 in benchmark, the choice and the one-asset economy respectively. $\gamma$ is $0.158,0.161$ and 0.161 in benchmark, the choice and the one-asset economy respectively. $\delta^{h}$ is $0.037,0.041$ and 0.043 in benchmark, the choice and the one-asset economy respectively. $\delta^{f}=0.003$ in the choice economy and 0 in the one-asset economy. 
Table 8: The wealth distribution for homeowners

\begin{tabular}{|c|c|c|c|c|c|c|}
\hline & \multicolumn{5}{|c|}{ Quintiles \% } & \multirow{2}{*}{$\begin{array}{l}\text { Gini } \\
\text { index }\end{array}$} \\
\hline & $1 \mathrm{st}$ & 2nd & $3 r d$ & 4 th & 5 th & \\
\hline & \multicolumn{6}{|c|}{ HOMEOWNERS WITH POSITIVE EARNINGS IN THE SCF-98 } \\
\hline Earnings & 3.81 & 9.46 & 14.41 & 20.43 & 51.87 & 0.479 \\
\hline Houses & 3.95 & 9.36 & 13.33 & 20.21 & 53.13 & 0.485 \\
\hline Financial assets & -7.71 & -1.73 & 1.24 & 7.88 & 100.30 & 0.938 \\
\hline Wealth & 0.69 & 3.15 & 6.21 & 12.58 & 77.35 & 0.745 \\
\hline$H / W_{(1)}$ & \multicolumn{2}{|c|}{194.00} & 91.81 & 67.05 & 24.33 & \\
\hline \multirow[t]{2}{*}{$H / W_{(2)}$} & 755.94 & 147.96 & 92.88 & 68.39 & 40.00 & \\
\hline & \multicolumn{6}{|c|}{ HOMEOWNERS IN THE CHOICE ECONOMY } \\
\hline Earnings & 6.30 & 10.20 & 14.24 & 21.09 & 48.16 & 0.408 \\
\hline Houses & 6.59 & 10.37 & 14.22 & 24.65 & 44.17 & 0.397 \\
\hline Financial assets & -4.03 & -2.28 & 1.69 & 14.77 & 89.84 & 0.875 \\
\hline Wealth & 0.90 & 2.03 & 6.35 & 17.78 & 72.93 & 0.728 \\
\hline$H / W_{(1)}$ & \multicolumn{2}{|c|}{226.50} & 83.30 & 48.28 & 21.61 & \\
\hline \multirow[t]{2}{*}{$H / W_{(2)}$} & 319.90 & 199.17 & 90.68 & 49.98 & 29.50 & \\
\hline & \multicolumn{6}{|c|}{ HOMEOWNERS IN THE VOLATILE CHOICE ECONOMY } \\
\hline Earnings & 4.51 & 8.64 & 13.54 & 21.39 & 51.92 & 0.449 \\
\hline Houses & 15.36 & 15.58 & 17.89 & 17.89 & 33.27 & 0.179 \\
\hline Financial assets & -2.09 & 3.32 & 8.01 & 13.20 & 77.57 & 0.776 \\
\hline Wealth & 4.72 & 8.26 & 11.30 & 14.76 & 60.95 & 0.560 \\
\hline$H / W_{(1)}$ & \multicolumn{2}{|c|}{93.56} & 54.68 & 43.24 & 19.00 & \\
\hline$H / W_{(2)}$ & 137.14 & 75.56 & 54.96 & 43.51 & 29.73 & \\
\hline
\end{tabular}

Notes: Households are ordered by the variable indicated in each row, except for the rows labeled ' $H / W$ ' in which households are ordered by total wealth, $W$. (1): Sum of housing wealth in the quintile divided by total wealth in the quintile. (2): The mean housing wealth to total wealth ratio in the quintile. 
Table 9: Distribution of houses and earnings for homeowners

\begin{tabular}{|c|c|c|c|c|c|c|}
\hline & \multicolumn{5}{|c|}{ Quintiles \% } & \multirow{2}{*}{$\begin{array}{l}\text { Gini } \\
\text { index }\end{array}$} \\
\hline & 1 st & 2nd & 3rd & 4 th & 5 th & \\
\hline & \multicolumn{6}{|c|}{ HOMEOWNERS WITH POSITIVE EARNINGS IN THE SCF-89 } \\
\hline Earnings & 3.89 & 10.01 & 15.02 & 21.12 & 49.94 & 0.458 \\
\hline \multirow[t]{2}{*}{ Houses } & 3.15 & 8.12 & 12.94 & 21.66 & 54.10 & 0.507 \\
\hline & \multicolumn{6}{|c|}{ HOMEOWNERS WITH POSITIVE EARNINGS IN THE SCF-92 } \\
\hline Earnings & 3.44 & 9.11 & 14.52 & 20.92 & 52.00 & 0.485 \\
\hline \multirow[t]{2}{*}{ Houses } & 3.76 & 8.71 & 13.61 & 20.72 & 53.19 & 0.491 \\
\hline & \multicolumn{6}{|c|}{ HOMEOWNERS WITH POSITIVE EARNINGS IN THE SCF-95 } \\
\hline Earnings & 3.65 & 9.26 & 14.53 & 20.63 & 51.90 & 0.483 \\
\hline \multirow[t]{2}{*}{ Houses } & 3.93 & 9.64 & 14.24 & 20.99 & 51.19 & 0.469 \\
\hline & \multicolumn{6}{|c|}{ HOMEOWNERS WITH POSITIVE EARNINGS IN THE SCF-98 } \\
\hline Earnings & 3.81 & 9.46 & 14.41 & 20.43 & 51.87 & 0.479 \\
\hline \multirow[t]{2}{*}{ Houses } & 3.95 & 9.36 & 13.33 & 20.21 & 53.13 & 0.485 \\
\hline & \multicolumn{6}{|c|}{ HOMEOWNERS WITH POSITIVE EARNINGS IN THE SCF-01 } \\
\hline Earnings & 3.48 & 8.70 & 13.44 & 19.83 & 54.55 & 0.510 \\
\hline \multirow[t]{2}{*}{ Houses } & 3.85 & 7.97 & 12.13 & 19.28 & 56.77 & 0.523 \\
\hline & \multicolumn{6}{|c|}{ HOMEOWNERS WITH POSITIVE EARNINGS IN THE SCF-04 } \\
\hline Earnings & 3.67 & 9.21 & 14.23 & 21.53 & 51.33 & 0.478 \\
\hline Houses & 3.46 & 7.84 & 11.78 & 19.19 & 57.70 & 0.535 \\
\hline
\end{tabular}

Notes: Households are ordered by the variable indicated in the corresponding row. Owned calculations using the Survey of Consumer Finances.

Table 10: Aggregate ratios and inequality indices for different down payments

\begin{tabular}{|c|c|c|c|c|c|c|c|c|}
\hline \multirow[b]{2}{*}{$\theta(\%)$} & \multicolumn{5}{|c|}{$\rho=0.05$} & $\overline{\rho \rho}=10$ & \multicolumn{2}{|c|}{$\rho=0$} \\
\hline & 0 & 5 & $20^{*}$ & 50 & 100 & 20 & 20 & 0 \\
\hline$\overline{Y Y}$ & 0.998 & 0.999 & 1.000 & 1.004 & 1.010 & 1.004 & 0.993 & 0.991 \\
\hline$K$ & 1.626 & 1.629 & 1.638 & 1.664 & 1.702 & 1.666 & 1.591 & 1.583 \\
\hline$H$ & 1.061 & 1.066 & 1.068 & 1.061 & 1.044 & 1.045 & 1.130 & 1.132 \\
\hline$K+H$ & 2.687 & 2.695 & 2.706 & 2.725 & 2.745 & 2.710 & 2.721 & 2.714 \\
\hline GDP & 1.080 & 1.080 & 1.081 & 1.082 & 1.084 & 1.081 & 1.082 & 1.082 \\
\hline$K / G P D$ & 1.505 & 1.508 & 1.515 & 1.537 & 1.569 & 1.540 & 1.470 & 1.463 \\
\hline$H / G D P$ & 0.989 & 0.987 & 0.988 & 0.980 & 0.963 & 0.966 & 1.045 & 1.046 \\
\hline$(K+H) / G D P$ & 2.494 & 2.496 & 2.504 & 2.517 & 2.532 & 2.506 & 2.515 & 2.510 \\
\hline$H / C$ & 1.395 & 1.394 & 1.396 & 1.383 & 1.358 & 1.363 & 1.477 & 1.479 \\
\hline$r(\%)$ & 3.996 & 3.972 & 3.909 & 3.730 & 3.473 & 3.714 & 4.250 & 4.312 \\
\hline Gini Index, $H$ & 0.483 & 0.483 & 0.483 & 0.491 & 0.506 & 0.473 & 0.499 & 0.497 \\
\hline Gini Index, $K$ & 0.936 & 0.935 & 0.930 & 0.920 & 0.887 & 0.929 & 0936 & 0.939 \\
\hline Gini Index, $W$ & 0.810 & 0.808 & 0.801 & 0.779 & 0.736 & 0.796 & 0.801 & 0.810 \\
\hline
\end{tabular}

Notes: *Benchmark case. All Parameters as in the benchmark economy except the parameters indicated. $K$ is capital, $H$ are houses, $W$ is wealth and $r$ is the interest rate. $\theta$ and $\rho$ are the down payment parameter and the adjustment cost parameter, respectively. Aggregates normalized by output, $Y$, of the benchmark model. 
Table 11: Wealth composition for different down payments

\begin{tabular}{ccrrrrr}
\hline \hline & & \multicolumn{5}{c}{ Wealth Quintiles } \\
\cline { 3 - 7 }$\theta$ & $\rho$ & 1st & 2nd & 3rd & 4th & 5th \\
\hline 0 & 0.05 & 2059.99 & 379.70 & 205.93 & 76.31 & 33.84 \\
5 & 0.05 & 1434.55 & 356.57 & 202.60 & 77.14 & 33.89 \\
$20^{*}$ & 0.05 & 459.35 & 310.71 & 194.06 & 76.37 & 33.73 \\
50 & 0.05 & 186.16 & 178.00 & 152.75 & 74.63 & 34.61 \\
100 & 0.05 & 95.36 & 93.21 & 90.25 & 69.72 & 37.78 \\
\hline 0.2 & 10 & 424.28 & 285.68 & 184.41 & 74.86 & 32.04 \\
0.2 & 0 & 463.86 & 345.42 & 212.42 & 72.58 & 37.13 \\
0 & 0 & 2599.92 & 471.22 & 218.35 & 72.93 & 36.90 \\
\hline
\end{tabular}

Notes: *Benchmark case. Numbers are the average residential house-wealth ratio in the quintile.

Table 12: The benchmark economy with more grid points

\begin{tabular}{lrrrrrr}
\hline \hline & \multicolumn{5}{c}{ Quintiles } & Gini \\
\cline { 2 - 6 } & 1st & 2nd & 3rd & 4th & 5th & coeff. \\
\hline Earnings, $E$ & 4.18 & 7.99 & 12.57 & 19.64 & 55.61 & 0.499 \\
Houses, $H$ & 4.04 & 8.09 & 13.35 & 23.46 & 51.06 & 0.483 \\
Financial assets, $A$ & -5.77 & -3.18 & -1.82 & 8.11 & 102.66 & 0.932 \\
Wealth, $W$ & 0.38 & 1.13 & 2.97 & 13.89 & 81.63 & 0.801 \\
$H / W_{(1)}$ & 339.90 & 181.64 & 66.99 & 24.09 & \\
$H / W_{(2)}$ & 456.24 & 314.89 & 196.35 & 74.70 & 33.81 & \\
\cline { 2 - 5 }
\end{tabular}

Notes: Households are ordered by the variable indicated in each row, except for the rows labeled ' $H / W$ ' in which households are ordered by total wealth, $W$. (1): Sum of housing wealth in the quintile divided by total wealth in the quintile. (2): The mean housing wealth to total wealth ratio in the quintile. 


\section{References}

Aiyagari, S. R. (1994). Uninsured idiosyncratic risk, and aggregate saving. Quarterly Journal of Economics 109, 659-684.

Budria, S., J. Díaz-Giménez, V. Quadrini, and J.-V. Ríos-Rull (2002). New facts on the distribution of earnings, income and wealth in the U.S. Federal Reserve Bank of Minneapolis Quarterly Review 21, 2-35.

Cagetti, M. and M. D. Nardi (2005). Entrepreneurship, frictions, and wealth. Federal Reserve Bank of Chicago WP, n. 9-2005.

Carroll, C. D. (2000). Why do the rich save so much? In J. B. Slemrod (Ed.), Does Atlas Shrug? The Economic Consequences of Taxing the Rich. Harvard University Press.

Castañeda, A., J. Díaz-Giménez, and J.-V. Ríos-Rull (2003). Accounting for earnings and wealth inequality. Journal of Political Economy 111, 818-857.

Chen, C.-N., T.-W. Tsaur, and T.-S. Rhai (1982). The gini coefficient and negative income. Oxford Economic Papers 34, 473-478.

Cooley, T. F. and E. C. Prescott (1995). Economic growth and business cycles. In T. F. Cooley (Ed.), Frontiers of Business Cycle Research, Chapter 1, pp. 1-38. Princeton: Princeton University Press.

Díaz-Giménez, J., E. C. Prescott, T. Fitzgerald, and F. Alvarez (1992). Banking in computable general equilibrium economies. Journal of Economic Dynamics and Control 16, 533-559.

Díaz-Giménez, J. and L. A. Puch (1998). Borrowing constraints in economies with indivisible household capital and banking: an application to the spanish housing market (1982-89). Investigaciones Económicas 22(3), 469-499.

Fernández-Villaverde, J. and D. Krueger (2002). Consumption and saving over the life cycle: How important are consumer durables? Proceedings of the 2002 North American Summer Meetings of the Econometeric Society.

Gervais, M. (2002). Housing taxation and capital accumulation. Journal of Monetary Economics 49, 1461-1489.

Gruber, J. and R. F. Martin (2003). Precautinary savings and the wealth distribution with illiquid durables. Federal Reserve Board.

Henderson, V. and Y. Ioannides (1983). A model of housing tenure choice. American Economic Review 73, 98-113.

Hopenhayn, H. and E. C. Prescott (1992). Stochastic monotonicity and stationary distributions for dynamic economies. Econometrica 60, 1387-1406.

Huggett, M. (1993). The risk free rate in heterogeneous-agents, incomplete insurance economies. Journal of Economic Dynamics and Control 17(5/6), 953-970.

Huggett, M. (1996, December). Wealth distribution in life-cycle economies. Journal of Monetary Economics 38(3), 469-494.

Judd, K. L. (1998). Numerical Methods in Economics. MIT Press.

Juster, F. T., J. P. Smith, and F. Sttaford (1999). The measurement and structure of household wealth. Labour Economics 6, 253-275.

Krusell, P. and A. Smith (1998). Income and wealth heterogeneity in the macroeconomy. Journal of Political Economy 106, 867-896. 
Luengo-Prado, M. J. (2006). Durables, nondurables, down payments and consumption excesses. Journal of Monetary Economics 53(7), 1509-1539.

Prescott, E. C. (1986). Theory ahead of business cycle measurement. Carnegie-Rochester Conference Series on Public Policy 25(0), 11-44. Also in Federal Reserve Bank of Minneapolis Quarterly Review, 10 (4), 9-22.

Quadrini, V. (2000). Entrepreneurship, saving and social mobility. Review of Economic Dynamics 3, 1-19.

Quadrini, V. and J.-V. Ríos-Rull (1997). Understanding the U.S. distribution of wealth. Federal Reserve Bank of Minneapolis Quarterly Review 21, 22-36.

Storesletten, K., C. Telmer, and A. Yaron (2004). Consumption and risk sharing over the life cycle. Journal of Monetary Economics 51, 609-633.

Tauchen, G. (1986). Finite state Markov-chain approximations to univariate and vector autoregressions. Economics Letters 20, 177-181. 